\title{
Pediatric reference values for chromium and mercury in urine in the City of Buenos Aires and Greater Buenos Aires
}

\author{
Giselle Areny, Biochemist ${ }^{a}$, Daniel E. González, Biochemist ${ }^{a}$, Diego Amoedo, M.D. ${ }^{b}$, \\ M. Cristina Salvay, M.D. ${ }^{c}$, Mónica B. De Marco, Biochemist ${ }^{a}$, Francisca Bales, Biochemist ${ }^{c}$, \\ Juan Barreto, Technician ${ }^{a}$, Miguel Brescovich, Technician ${ }^{a}$, Mario Vallejo, Technician ${ }^{a}$ \\ and Silvia Villafañe, Biochemist ${ }^{a}$
}

\begin{abstract}
Introduction. Due to the heavy industrialization of the Autonomous City of Buenos Aires and Greater Buenos Aires, the population may have become exposed to metals. To assess the level of exposure to chromium and mercury in children, it is critical to have local reference values (RVs). Our objective was to determine pediatric RVs for chromium and mercury in a single urine sample. Population and methods: Children who werenot exposed to the studied contaminants and who attended the Department of Low Risk Conditions and the Daycare Center Office of Hospital de PediatríaS.A.M.I.C. "Prof. Dr.Juan P. Garrahan" wereincluded. Urinary chromium (UCr), urinary mercury $(\mathrm{UHg})$, and urinary creatinine were measured. The p95 and its corresponding $95 \%$ confidence interval(CI) were estimated based on the RV concept proposed by the German Human Biomonitoring Commission.

Results: The study included 160 patients. A total of 144 samples from children aged 1-17 years (median: 7 years) were collected. $\mathrm{UCr}$ was measured in 137 samples and UHg, in 129 samples. The median value of chromium was $0.54 \mu \mathrm{g} / \mathrm{g}$ of creatinine (range, undetectable to 3.06), while that of mercury was $0.49 \mu \mathrm{g} / \mathrm{g}$ of creatinine (range, undetectable to 7.57).

Conclusions: The RVs for UCr were up to $1.5 \mu \mathrm{g} / \mathrm{L}$ [1.2-2.8] and up to $2.2 \mu \mathrm{g} / \mathrm{g}$ of creatinine [1.8-3.0], and for $\mathrm{UHg}$, up to $2.5 \mu \mathrm{g} / \mathrm{L}$ [1.8-4.8] and $3.2 \mu \mathrm{g} / \mathrm{g}$ of creatinine [2.5-4.7].

Key words: chromium, mercury, urine, pediatrics, reference values.
\end{abstract}

http:/ / dx.doi.org/10.5546/ aap.2019.eng.245

"Prof. Dr. Juan

P. Garrahan,"

Autonomous City of

Buenos Aires.

E-mail address:

Giselle Areny, Biochemist:

labtoxicologia@

garrahan.gov.ar

Funding:

None.

Conflict of interest:

None.

Received: 5-16-2018

Accepted: 1-28-2019

\section{INTRODUCTION}

There is a worldwide growing concern for environment protection and its direct action on people's health. Industrial activities have become necessary for modern life and, in developing countries, the resulting environmental hazards are even more serious due to the limited financial, scientific, technological, and human resources. The Autonomous City of Buenos Aires and Greater Buenos Aires comprise a region of heavy industrial development. The Matanza-Riachuelo River Basin (MRRB) encompasses a broad range of industrial facilities that have been declared as contaminating agents: tanneries; electroplating and electroplate-related plants; waste carriers and treatment plants; and rubber, metalworking, plastic, chemistry, glass, electric power, meat processing, food, textile, paper, agricultural, and livestock industries. ${ }^{1}$

In Argentina, in recent years, the population exposed to contamination along the MRRB has been studied. Due to the characteristics of the industries that dump their waste into the river and the environment in general, it was decided to study and monitor the population exposure to heavy metals (lead, chromium, and mercury) and other toxic agents.

The diagnosis and follow-up of lead exposure are done based on blood lead levels, whose reference values (RVs) have been widely studied. ${ }^{2,3,4}$ If a subject is suspected to have been exposed to chromium and mercury, a 24-hour urine collection is the sample of choice, and the RVs 
for this type of sample have been described..$^{5-8}$ In addition, at present, a single urine sample is used to assess groups of people and to carry out population studies because it can be collected more easily. This has been recommended by international programs, such as the German Environmental Survey (GerES) ${ }^{9}$ in Germany and the National Health and Nutrition Examination Survey (NAHNES) $)^{10}$ in the United States.

Updated and adequate RVs for our hospital population are critical to interpret laboratory results. The laboratory has three reasons to establish its own RVs and assess those obtained from the international and national bibliography: (1) over the years, the methodologies for metal measurement have advanced in terms of sensitivity and precision,; ${ }^{11}$ (2) people have different responses to toxic metal exposure due to genetic causes, diet, lifestyle, and demographic characteristics; ${ }^{12}$ and (3) there is no evidence in relation to RVs for single urine samples in pediatrics in our country. ${ }^{13}$

The objective of this study was to determine the RVs for chromium and mercury in a single urine sample in the pediatric population of the Autonomous City of Buenos Aires and Greater Buenos Aires.

\section{POPULATION AND METHODS}

During 2011 and 2014, the patients who attended the Department of Low Risk Conditions and the Daycare Center Offices of Hospital de Pediatría S.A.M.I.C. "Prof. Dr. Juan P. Garrahan" were invited to participate in the study until reaching a sample size of more than 120 participants. Inclusion criteria were living in the Autonomous City of Buenos Aires or Greater Buenos Aires, age between 0 and 18 years, and voluntarily agreeing to participate; to this end, parents were asked to provide their informed consent and authorization was requested to the Hospital Ethics Committee.

Exclusion criteria were the following:

- Children sharing their household with people who worked in a setting at risk for chromium or mercury contamination or who performed a risk activity in the house or nearby.

- Children who had a chronic disease that may affect liver and kidney metabolism.

Single urine samples were requested after at least 3 hours of the last voiding.

The following levels were measured:

- Urinary chromium (UCr), using a graphite furnace atomic absorption spectrometry (GFAAS), VARIAN AA240Z-GTA120, limit of detection (LOD): $0.3 \mu \mathrm{g} / \mathrm{L}$.

- Urinary mercury (UHg), using a cold vapor atomic absorption spectrometry, VARIAN AA240FS with hydride generation, LOD: $0.4 \mu \mathrm{g} / \mathrm{L}$.

- Urinary creatinine (UCreat), using an automatic kinetic Jaffe method, Cobas 6000, ROCHE. UCreat was measured in all samples for dilution adjustment and to express results in $\mu \mathrm{g} / \mathrm{g}$ of creatinine.

Statistical calculations were made using the MedCalc version 12.7 and EPIDAT version 3.1 software. The Kolmogorov-Smirnov test was used to analyze for normal distribution, and a multiple regression analysis, to examine the correlation between outcome measures. A $p$ value $<0.05$ was regarded as significant for all tests.

The RVs were determined estimating the $95^{\text {th }}$ percentile (p95) and its corresponding $95 \%$ confidence interval (CI), as defined by the German Human Biomonitoring Commission, based on the recommendations by the International Federation of Clinical Chemistry and Laboratory Medicine (IFCC) and the International Union of Pure and Applied Chemistry (IUPAC). ${ }^{14}$

\section{RESULTS}

A total of 160 patients were included; none met exclusion criteria (Figure 1). Nine patients did not submit their urine sample to the lab due to personal issues. Out of the 151 samples that were received, 7 were excluded from analysis because UCreat levels were out of the range of validity (between $0.3 \mathrm{~g} / \mathrm{L}$ and $3 \mathrm{~g} / \mathrm{L}$ ), either because they were too diluted or too concentrated (World Health Organization [WHO], 1996). ${ }^{15}$ For the remaining 144 samples, the median UCreat level was $0.97 \mathrm{~g} / \mathrm{L}$ (range: 0.30-2.84 g/L). UCr and UHg were measured in 122 samples. Only $\mathrm{UCr}$ was measured in 15 samples, while only $\mathrm{UHg}$ was established in 7 , because the sample volume was not enough to measure both metals. The population demographic data are described in Table 1.

Results indicated that $18 \%$ of UCr levels and $44 \%$ of UHg levels were below the method's LOD. For statistical calculations, these results were assigned a value equal to half of the LOD. ${ }^{16}$

Figure 2 shows data distribution; none of the data followed a normal distribution $(p<0.05)$. A significant correlation was established between $\mathrm{UCr}$ and UHg levels and age $(p<0.001)$, but no correlation to sex was observed. However, when creatinine levels were included in the multiple 
regression analysis as an independent outcome measure, as suggested by Barr et al., 2004, ${ }^{17}$ no relation was observed anymore between metal levels and age.

Since values did not show a normal distribution, the median and range were used as measures of central tendency and dispersion. The following percentiles were estimated: p25, p50, p90, p95, and p97.5. Table 2 shows the analysis of results.

\section{DISCUSSION}

In this study, the sample size was at least 120 participants, as suggested by the Clinical \& Laboratory Standards Institute (CLSI) (NCCLSC28-A2), ${ }^{18}$ and metal levels were reported in two ways: with and without adjustment for UCreat.

As children grow, their muscle mass increases, so they release more UCreat and, once results are adjusted for it, their metal levels decrease. Future

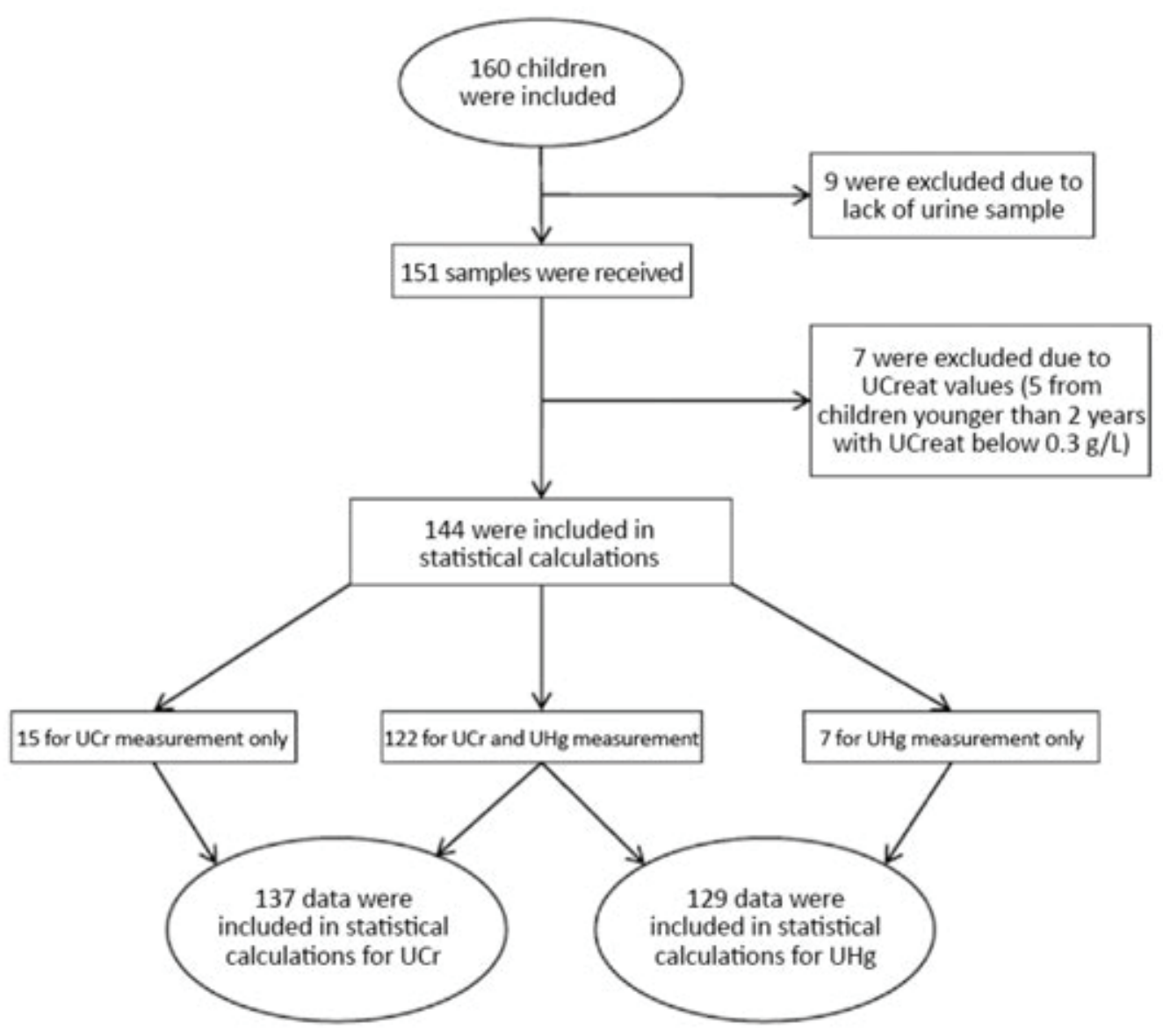

UCreat: urinary creatinine; UCr: urinary chromium; UHg: urinary mercury.

TABle 1. Demographic data

\begin{tabular}{llcc}
\hline & & UCr $(\mathbf{n}=\mathbf{1 3 7})$ & UHg $(\mathbf{n}=\mathbf{1 2 9})$ \\
\hline Sex & Female & $69(50.4 \%)$ & $65(50.4 \%)$ \\
Age (years old) & Male & $68(49.6 \%)$ & $64(49.6 \%)$ \\
& Median & 7 & 7 \\
N by age range & Range & {$[1-17]$} & {$[2-17]$} \\
& 1-2 years old & 4 & 1 \\
& 3-8 years old & 81 & 75 \\
& 9-12 years old & 33 & 34 \\
& 13-17 years old & 19 & 19 \\
\hline
\end{tabular}

UCr: urinary chromium; UHg: urinary mercury. 
FIGURE 2. Distribution of urinary chromium $(A)$ and urinary mercury $(B)$ values
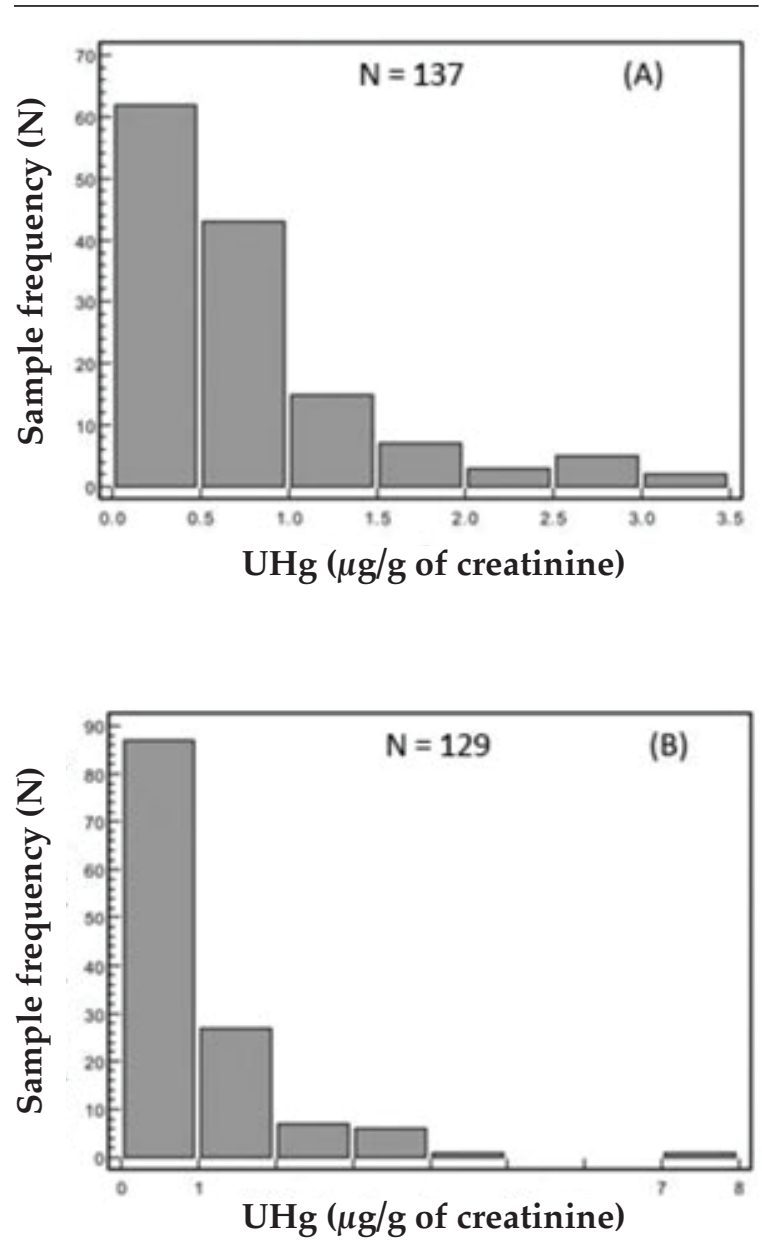

UCr: urinary chromium; UHg: urinary mercury.

studies should assess the RVs in a larger sample to establish differences by age range. The p95 and its corresponding $95 \%$ CI were estimated, which allowed to compare these to the reference values $\left(\mathrm{RV}_{95}\right)$ proposed by biomonitoring programs, such as the German Environmental Survey
(GerES) and the National Health and Nutrition Examination Survey (NHANES), and to studies that used the same criterion. Tables 3 and 4 show the comparison to the bibliography.

The $\mathrm{RV}_{95}$ proposed by the German Human Biomonitoring (HBM) Commission is based on the $95 \%$ CI corresponding to the p95 of the concentration levels in the relevant matrix of the reference population. ${ }^{19}$ The $R V_{95}$ has different uses in public health. It provides a basis to identify subjects or subpopulations with high levels of exposure compared to baseline levels in the general population. It also allows to assess temporary changes in exposure to chemical substances, usage patterns, and effectiveness of actions targeted at reducing exposure. If values are above the $\mathrm{RV}_{95}$, it suggests the need for followup to establish the cause. ${ }^{20}$

\section{Urinary chromium:}

As seen in Table 3, only one study was found in Italy, conducted by Alimonti $(2000)^{21}$ in the pediatric population using single urine samples. That study found a p95 value, which accounted for half of that observed in this study. The comparison to adult populations was varied. Similarities were observed to a biomonitoring done in France ${ }^{22}$ and a study conducted in Buenos Aires, ${ }^{13}$ which found, for the p97.5, levels of $1.47 \mu \mathrm{g} / \mathrm{L}$ and $2.68 \mu \mathrm{g} / \mathrm{g}$ of creatinine (close to our values, Table 2). A study conducted in the south of Brazil ${ }^{23}$ showed considerably higher levels than in our study, contrary to a study done in the United Kingdom, ${ }^{24}$ which found a p95 closer to half of that obtained in our study.

Chromium(III) is an essential nutrient from food, necessary for the body in small amounts. Chromium(VI) is a carcinogen that comes mostly from anthropogenic sources. It may be found in the air, soil, and water after it is released by industries that use chromium,

TABLE 2. Descriptive statistics for chromium and mercury in urine in a single sample

\begin{tabular}{lcccc}
\hline & $\mu \mathrm{g} / \mathrm{L}$ & $\mathrm{UCr}$ & \multicolumn{2}{c}{$\mathrm{UHg}$} \\
\hline Median & 0.6 & $\mu \mathrm{g} / \mathrm{g}$ of creat. & $\mu \mathrm{g} / \mathrm{L}$ & $\mu \mathrm{g} / \mathrm{g}$ of creat. \\
Range & <OD -4.4 & 0.54 & 0.48 & 0.49 \\
p25 & $<$ LOD -3.06 & $<$ LOD -6.30 & $<$ LOD -7.57 \\
p50 & LOD & $<$ LOD & $<$ LOD & $<$ LOD \\
p90 & 0.60 & 0.54 & 0.48 & 0.49 \\
p95 & 1.20 & 1.66 & 1.74 & 2.25 \\
p97.5 & 1.47 & 2.21 & 2.46 & 3.20 \\
\hline
\end{tabular}

< LOD: below the limit of detection.

UCr: urinary chromium; UHg: urinary mercury; creat.: creatinine. 
such as electroplating plants, tanneries, textile production, and chromium-based manufacturing. It may also be released into the environment through natural gas, oil or carbon burning. ${ }^{25}$ Exposure to chromium in the Autonomous City of Buenos Aires and Greater Buenos Aires may be associated with the industrial activities developed in the area.

The differences observed in the RVs may be due to several reasons. These were populations from different countries with different environmental exposures and eating patterns. The pediatric study by Alimonti (2000) and this study were conducted more than 10 years apart. The methodology used in all the studies found in the bibliography is the inductively coupled plasma mass spectrometry (ICP-MS), which is more sensitive than the GF-AAS.

\section{Urinary mercury:}

In pediatrics, there is a larger amount of bibliography in relation to UHg. Table 4 shows that the RVs in this study were higher, except for the study conducted in the Democratic Republic of the Congo (DRC), ${ }^{26}$ whose values were five times higher than ours. The data from the DRC are related to the production and use of mercurycontaining skin whitening creams and antiseptic soaps.

The Canadian Health Measures Survey (CHMS) ${ }^{20}$ in accordance with the latest German Environmental Survey (GerES IV), ${ }^{27}$ obtained a

TABLE 3. Comparison to international reference values for urinary chromium

\begin{tabular}{|c|c|c|c|c|}
\hline Study & Age (years old) & $\mathbf{n}$ & p95 & {$[95 \% \mathrm{CI}]$} \\
\hline Argentina (Buenos Aires) & $1-17$ & 137 & $1.4 \mu \mathrm{g} / \mathrm{L}$ & {$[1.2-2.8]$} \\
\hline This study & & & $2.2 \mu \mathrm{g} / \mathrm{g}$ of creat. & {$[1.8-3.0]$} \\
\hline Brazil, ${ }^{(23)}$ & $18-74$ & 175 men & $6.11 \mu \mathrm{g} / \mathrm{g}$ of creat. & - \\
\hline 2013 & & 65 women & $5.19 \mu \mathrm{g} / \mathrm{g}$ of creat. & \\
\hline France, ${ }^{(22)}$ & $20-59$ & 1910 & $1.60 \mu \mathrm{g} / \mathrm{L}$ & [1.52-1.66] \\
\hline $2008-2010$ & & & $1.80 \mu \mathrm{g} / \mathrm{g}$ of creat. & [1.71-1.92] \\
\hline $\begin{array}{l}\text { United Kingdom, } \\
2014\end{array}$ & $18-66$ & 132 & $\begin{array}{c}0.79 \mu \mathrm{g} / \mathrm{L} \\
1.3 \mu \mathrm{g} / \mathrm{g} \text { of creat.(a) }\end{array}$ & - \\
\hline $\begin{array}{l}\text { Italy (Rome), }{ }^{(21)} \\
2000\end{array}$ & $6-10$ & 131 & $1.07 \mu \mathrm{g} / \mathrm{g}$ of creat. & [0.76-2.06] \\
\hline
\end{tabular}

(a) Value reported in $\mu \mathrm{mol} / \mathrm{mol}(2.89 \mu \mathrm{mol} / \mathrm{mol})$; a 0.45 conversion factor was used. CI: confidence interval; creat.: creatinine.

TABLE 4. Comparison to international reference values for urinary mercury

\begin{tabular}{|c|c|c|c|c|}
\hline Study & Age (years old) & $\mathbf{n}$ & p95 & {$[95 \% \mathrm{CI}]$} \\
\hline $\begin{array}{l}\text { Argentina (Buenos Aires) } \\
\text { This study }\end{array}$ & $2-17$ & 129 & $\begin{array}{c}2.5 \mu \mathrm{g} / \mathrm{L} \\
3.2 \mu \mathrm{g} / \mathrm{g} \text { of creat. }\end{array}$ & $\begin{array}{l}{[1.8-4.8]} \\
{[2.5-4.7]}\end{array}$ \\
\hline $\begin{array}{l}\text { Germany (GerES IV), }{ }^{(27)} \\
2003-2006\end{array}$ & $3-14$ & $\begin{array}{c}1612^{(\mathrm{a})} \\
68^{(\mathrm{b})} \\
39^{(\mathrm{c})}\end{array}$ & $\begin{array}{l}0.5 \mu \mathrm{g} / \mathrm{L} \\
1.5 \mu \mathrm{g} / \mathrm{L} \\
3.1 \mu \mathrm{g} / \mathrm{L}\end{array}$ & $\begin{array}{c}{[0.39-0.50]} \\
- \\
-\end{array}$ \\
\hline $\begin{array}{l}\text { United States (NHANES), }{ }^{(29)} \\
\text { 2013-2014 }\end{array}$ & $\begin{array}{l}6-11 \\
12-19\end{array}$ & $\begin{array}{l}401 \\
452\end{array}$ & $\begin{array}{c}0.89 \mu \mathrm{g} / \mathrm{L} \\
1.11 \mu \mathrm{g} / \mathrm{g} \text { of creat. } \\
1.02 \mu \mathrm{g} / \mathrm{L} \\
0.85 \mu \mathrm{g} / \mathrm{g} \text { of creat. }\end{array}$ & $\begin{array}{l}{[0.64-1.10]} \\
{[0.71-1.72]} \\
{[0.61-1.81]} \\
{[0.58-1.07]}\end{array}$ \\
\hline $\begin{array}{l}\text { Canada (CHMS), }{ }^{(20)} \\
2007-2013\end{array}$ & $3-5$ & 214 & $0.58 \mu \mathrm{g} / \mathrm{L}$ & [0.29-0.87] \\
\hline $\begin{array}{l}\text { DR Congo, } \\
2015\end{array}$ & $1-14$ & 125 & $\begin{array}{c}19.3 \mu \mathrm{g} / \mathrm{L} \\
15.3 \mu \mathrm{g} / \mathrm{g} \text { of creat. }\end{array}$ & $\begin{array}{l}{[18.7-20.1]} \\
{[12.8-16.8]}\end{array}$ \\
\hline $\begin{array}{l}\text { China, }{ }^{(30)} \\
2014\end{array}$ & $0-6$ & 1072 & $1.42 \mu \mathrm{g} / \mathrm{L}$ & [1.31-1.51] \\
\hline
\end{tabular}
(a) No dental amalgam fillings.
(b) 1-2 dental amalgam fillings.
(c) More than 2 dental amalgam fillings.
CI: confidence interval; creat.: creatinine. 
p95 that was five times lower than that observed in this study and in the GerES II 1990/1992 ${ }^{28}$, which was $3.9 \mu \mathrm{g} / \mathrm{L}$. The decrease observed in the German population and the findings from Canada are attributed to the reduction in the use of dental amalgam fillings and the more stringent restrictions on fish consumption in the populations included in those studies. One of the limitations of this study is that it did not collect such demographic data about the studied population. Compared to the NHANES values ${ }^{29}$ and to the findings of a Chinese study, ${ }^{30}$ our results are higher, but to a lesser extent. In 2014, a study was done in Mexico (Mexico City) ${ }^{31}$ to analyze UHg levels in children; it estimated the p90 $(1.89 \mu \mathrm{g} / \mathrm{L})$, which was similar to the one found in our study $(1.74 \mu \mathrm{g} / \mathrm{L}$, Table 2$)$.

The HBM Commission has established human biomonitoring (HBM-1) values below which there are not risks for adverse effects on health and that, therefore, require no action. ${ }^{32}$ In the case of mercury, HBM- 1 values were $7 \mu \mathrm{g} / \mathrm{L}$ and $5 \mu \mathrm{g} / \mathrm{g}$ of creatinine (also proposed by the WHO). ${ }^{33}$ In this study, the p95 and the upper limit of the $95 \%$ CI were below these recommendations.

The main anthropogenic sources of mercury are releases from fossil-fuel burning (carbon, gas, oil), paper-manufacturing chlor-alkali operations, medical equipment (thermometers, dental amalgam), fluorescent lamps, cement plants, car headlights, waste treatment plants, rubbish dumps, cremation, and paint. ${ }^{34}$ These may all be found in the Autonomous City of Buenos Aires and Greater Buenos Aires.

Argentina has adopted different initiatives aimed at reducing the release of mercury into the environment: ratifying the Minamata Convention (whose purpose is to gradually eliminate mercury use and emissions by 2020), reducing dental amalgam use, and implementing policies to stop using mercury-containing medical equipment. The Autonomous City of Buenos Aires has passed Law $\mathrm{N}^{\circ} 1854$, known as the Zero Waste Act, which establishes progressive goals to reduce the final disposal of solid urban waste and prohibits waste incineration. It would be desirable for Argentina to implement a national human biomonitoring program to establish baseline values, assess the effectiveness of implemented interventions, and compare values at a regional and international level.

In relation to $U C r$, no recent pediatric studies were found in the bibliography that would allow us to compare our results. And in relation to
$\mathrm{UHg}$, no studies conducted in Argentina were found. This study met the objective of filling a gap regarding pediatric RVs for chromium and mercury corresponding to the Autonomous City of Buenos Aires and Greater Buenos Aires. We encourage the conduct of further studies with the same objective, both in the same area and other regions of Argentina.

\section{CONCLUSION}

We propose the following RVs for the studied pediatric population: for chromium, up to $2.2 \mu \mathrm{g} / \mathrm{g}$ of creatinine $(1.5 \mu \mathrm{g} / \mathrm{L})$, and for mercury, up to $3.2 \mu \mathrm{g} / \mathrm{g}$ of creatinine $(2.5 \mu \mathrm{g} / \mathrm{L})$.

\section{REFERENCES}

1. ACUMAR. Listado de Agentes Contaminantes (y AC Reconvertidos). 2017. [Accessed on: April 23 ${ }^{\text {rd }}$, 2018]. Available at: http://datos.acumar.gob.ar/dataset/ agentes-contaminantes-de-la-cuenca-matanza-riachueloagosto-2017.

2. Hornung R W, Lanphear B P, Dietrich K N. Age of greatest susceptibility to childhood lead exposure: a new statistical approach. Environl Health Perspect. 2009; 117(8):1309-12.

3. Lanphear BP, Hornung RW, Khoury J, Yolton K, et al. Low-level environmental lead exposure and children's intellectual function: an international pooled analysis. Environ Health Perspect. 2005; 113(7):894-9.

4. AmoedoD, Gaioli M, González DE. Intoxicación por Plomo $(\mathrm{Pb})$ en niños. Med Infant. 2008; 15(4):367-9.

5. EnviromentalProtection Agency. Evaluación de la exposición al mercurio: información para profesionales sanitarios. 2009. [Accessed on: April 24 ${ }^{\text {th }}, 2018$ ]. Available at: https: / / www.atsdr.cdc.gov/ mercury/docs/physician_ hg_flier_es.pdf.

6. Minoia C, Sabbioni E, Apostoli P, Pietra R, et al. Trace element reference values in tissues from inhabitants of European Community I. A study of 46 elements in urine, blood and serum of Italian Subjects. Sci Total Environ. 1990; 95:89-105.

7. White M A, Sabbioni E. Trace element reference values in tissues from inhabitants of the European Union. X. A study of 13 elements in blood and urine of a United Kingdom population. Sci Total Environ. 1998;216(3):253-70.

8. World Health Organization. Inorganic chromium (VI) compounds. Concise International Chemical Assessment Document 78. 2013. [Accessed on: April 24th ${ }^{\text {th }}$ 2018]. Available at: http://www.who.int/ipcs/publications / cicad/cicad_78.pdf?ua=1.

9. German Eñvironmental Survey, GerES 2014-2017. [Accessed on: September 17 ${ }^{\text {th }}, 2018$ ]. Available at: https: / / www.umweltbundesamt.de/en/topics / health/ assessing-environmentally-related-health-risks / germanenvironmental-surveys / german-environmental-survey2014-2017-geres-v\#textpart-1.

10. Center for Disease Control and Prevention. National Health and Nutrition Examination Survery. [Accessed on: September $17^{\text {th }}$, 2018]. Available at: https: / / www.cdc.gov / nchs/nhanes/index.htm.

11. Sieniawska CE, Jung LC, Olufadi R, Walker V. Twenty-fourhour urinary trace element excretion: referenceintervals and interpretive issues. Ann Clin Biochem. 2012; 49(Pt 4):341-51.

12. Ewers U, Krause C, Schulz C, Wilhelm M. Reference Values and human biological monitoring values for environmental 
toxins. Report on the work and recommendations of the Commission on Human Biological Monitoring of the German Federal Environmental Agency. Int Arch Occup Environ Health. 1999; 72(4)255-60.

13. ElKassisse Y, Piñeiro A, Gamba Aragón A, Sosa G, et al. Valores de referencia de cromo urinario en poblaciones de área metropolitana de Buenos Aires no expuestas profesionalmente. Acta Toxicol Argent. 2004; 12(Supl):18-9.

14. Umwelt Bundesamt. Reference and HBM values. 2015. [Accessed on: October 21st, 2018]. Available at: https: / / www.umweltbundesamt.de/en/topics/health/ commissions-working-groups/human-biomonitoringcommission/reference-hbm-values.

15. World Health Organization. Trace Elements in Human Nutrition and Health. Geneva: OMS; 1996.

16. Taylor JK. Quality Assurance of Chemical Measurements. Chelsea, MI: Lewis Publishing; 1987.

17. Barr DB, Wilder LC, Caudill SP, Gonzalez AJ, et al. Urinary creatinine concentrations in the U.S. population: implications for urinary biologicmonitoring measurements. Environ Health Perspect. 2005;133(2):192-200.

18. Clinical and Laboratory Standards Institute. C28-A2 How to Define and Determine Reference Intervals in the Clinical Laboratory; Approved Guideline. $2^{\text {nd }}$ ed. [Accessed on: February 1 1t, 2019]. Available at: http:/ / www.zxyjhjy. com/upload/attached / file/20170406/20170406120112_ 8797.pdf.

19. Schulz C, Wilhelm M, Heudorf U, Kolossa-Gehring M. Reprint of "Update of reference and HBM values derived by the German Human Biomonitoring Commission." Int J Hyg Environ Health. 2012; 215(2):150-8.

20. Saravanabhavan G, Werry K, Walker M, Haines D, et al. Human biomonitoring reference values for metals and trace elements in blood and urine from the Canadian Health Measures Survey 2007-2013. Int J Hyg Environ Health. 2017; 220(2 Pt A):189-200.

21. Alimonti A, Petrucci F, Krachler M, Bocca B, Caroli S. Reference values for chromium, nickel and vanadium in urine of youngsters from the area of Rome. J Environ Monit. 2000; 2(4):351-4.

22. Nisse C, Tagne-Fotso R, Howsam M, Richeval C, et al. Blood and urinary levels of metals and metalloids in the general adult population of Northern France: The IMEPOGE study, 2008-2010. Int J Hyg Environ Health. 2017; 220(2 Pt B):341-63.

23. Rocha GH, Steinbach C, Munhoz J, Madia M, et al. Trace metal levels in serum and urine of a population in southern Brazil. J Trace Elem Med Biol. 2016; 35:61-5.
24. Morton J, Tan E, Leese E, Cocker J. Determination of 61 elements in urine collected from a non-occupationally exposed UK adult population. Toxicol Lett. 2014; 231(2): 179- 93.

25. Agencia para Sustancias Tóxicas y el Registro de Enfermedades. Resúmenes de Salud Pública - Cromo (Chromium). [Accessed on: October 29 $9^{\text {th }}, 2018$ ]. Available at: https://www.atsdr.cdc.gov/es/phs/es_phs7.html.

26. Tuakuila J, Kabamba M, Mata H, Mbuyi F. Tentative reference values for environmental pollutants in blood or urine from the children of Kinshasa. Chemosphere. 2015; 139:326-33.

27. Schultz C, Angerer J, Ewers U, Heudorf U, et al. Revised and new reference values for environmental pollutants in urine or blood of children in Germany derived from the German Environmental Survey on Children 2003-2006 (GerES IV). Int J Hyg Environ Health. 2009; 212(6):637-47.

28. Schulz C, Conrad A, Becker K, Kolossa-Gehring M, et al. Twenty years of German Environmental Survey (GerES): Human biomonitoring-temporal and spatial (West Germany / East Germany) differences in population exposure. Int J Hyg Environ Health. 2007; 210(3-4):271-97.

29. Center for Disease Control and Preventions. Fourth National Report on Human Exposure to Environmental Chemicals Updated Tables. 2018;1. [Accessed on: April 24 $4^{\text {th }}, 2018$ ]. Availableat:https:/ / www.cdc.gov/exposurereport/pdf/ FourthReport_UpdatedTables_Volume1_Mar2018.pdf.

30. Chen G, Chen X, Yan C, Wu X, Zeng G. Surveying Mercury Levels in Hair, Blood and Urine of under 7-Year Old Children from a Coastal City in China. Int J Environ Res Public Health. 2014; 11(11)12029-41.

31. Basu N, Tutino R, Zhang Z, Cantonwine D, et al. Mercury levels in pregnant women, children, and seafood from Mexico City. Environ Res. 2014; 135:63-9.

32. Schulz C, Angerer J, Ewers U, Kolossa-Gehring. The German Human Biomonitoring Commission. Int J Hyg Environ Health. 2007; 210(3-4):373-82.

33. World Health Organization. Guidance for identifying populations at risk from mercury exposure. Geneva. 2008. [Accessed on: April 25 ${ }^{\text {th }}$, 2018]. Available at: http:/ / www.who.int/ foodsafety / publications / risk-mercuryexposure/en/.

34. Organización Mundial de la Salud. El mercurio y la salud. 2017. [Accessed on: October 29 $9^{\text {th }}$, 2018]. Available at: http:/ / www.who.int/es/news-room/ fact-sheets / detail/mercuryand-health. 